Referential and Relational Discourse Coherence in Adults and Children 


\section{Studies on Language Acquisition}

Editor

Peter Jordens

Volume 53 


\section{Referential and Relational Discourse Coherence in Adults and Children}

Edited by

Natalia Gagarina, Renate Musan

DE GRUYTER

MOUTON 
ISBN 978-1-5015-1870-6

e-ISBN (PDF) 978-1-5015-1015-1

e-ISBN (EPUB) 978-1-5015-0999-5

ISSN 1861-4248

Library of Congress Control Number: 2020931603

Bibliographic information published by the Deutsche Nationalbibliothek

The Deutsche Nationalbibliothek lists this publication in the Deutsche Nationalbibliografie; detailed bibliographic data are available on the Internet at http://dnb.dnb.de.

(C) 2020 De Gruyter Inc., Boston/Berlin

Typesetting: Amelie Lohmann

Printing and binding: CPI books $\mathrm{GmbH}$, Leck

www.degruyter.com 